\title{
Broiler Breeder Behavior and Egg Production as Function of Environmental Temperature
}

Duthor(s)
Pereira DF
Nääs IA ${ }^{2}$
Romanini CEB ${ }^{3}$
Salgado DD
Pereira GOT
1 Assistant professor UNESP-TUPÃ, doctoral
student FEAGRI-UNICAMP.
2 Professor FEAGRI-UNICAMP.
3 Undergraduate Student/CNPQ-PIBIC,
FEAGRI-UNICAMP.
4 Master's student/CNPq, FEAGRI-UNICAMP.
5 Undergraduate student, PUC-Campinas.

\section{Mail Address}

\section{DF Pereira}

Rua Domingos da Costa Lopes, 780

Jd. Unesp

17.602-496. Tupã, SP, Brazil

E-mail: danilo@tupa.unesp.br

\section{Keywords}

Broiler breeder, heat stress, behavioral pattern.

\section{INTRODUCTION}

Broiler production has experienced significant technological development in the last 30 years. The Brazilian broiler industry has reached a high degree of competitiveness in the 1980s, and it is currently the market leader in exports. Improved live performance efficiency and implementation of quality control in the broiler production chain has been constant in the Brazilian industry.

Animal welfare has become a major requirement for intensive production. Beak trimming, stocking density, free access to feed, heat stress, and ammonia in the air are important issues, which have been regulated by several countries. The lack of effective assessments of animal welfare hinders the present advance of animal welfare. Dawkins (2003) summarized the concerns on animal welfare in two questions: Are the animals healthy? Do they have access to what they need? While the first question is relatively easy to answer, whereas the second is very complex, as it involves concepts that are not very well understood under the engineering standpoint, and are not simple to measure.

Several authors (Duncan \& Mench, 1993; Snowdon, 1999; Puma et al., 2001) studied poultry behavior, and used some behavioral responses, such as aggression and prostration, to assess welfare. Kristensen et al. (2000) studied the behavioral preferences of laying hens (Gallus gallus domesticus) in the different environments found in commercial poultry houses, and their results suggest that some specific situations may be aversive to hens. The choice animals make when faced with different environments, and the amount of stress shown when making those behavioral choices may indicate whether or not their needs are actually supplied (Dawkins, 2003). Studying the behavioral expression of layers as to environmental ammonia concentration Wathes et al. (2002) compared their behavior in pens with fresh air, air with 25ppm, or 45 ppm of ammonia. The results showed that hens preferred fresh air because the performance of behaviors such as foraging, preening, and laying down in this environment was significantly higher than in pens with higher ammonia concentration. However, other behaviors such as nesting, drinking, and walking presented the same frequency in all treatments.

Studies on the use of pen space by domestic chickens reared under commercial conditions usually involve the analysis of movement of few birds (Arnould \& Faure, 2004). Social behavior within a group is influenced by external factors, such as the environment, and may influence flock productivity (Campos, 2000). Estevez et al. (2003) suggested that broilers adopt different social strategies and behaviors as the group size increases, and therefore this observation has to be taken into consideration when a single sample of broilers is observed within a large group. For instance, aggression is considered a dynamic process in domestic fowl, and seems to be more frequent in larger groups. 


\section{Pereira DF, Nääs IA, Romanini CEB, Salgado DD, Pereira GOT}

Pettit-Riley et al. (2002) studied the effects of growth and the access to perch on the aggressive behavior of broilers, and found that aggressive behavioral responses increase according to growth rate as well as broiler density on the perch. The complexity of the poultry housing environment, in terms of the adequate use of internal spaces, was researched by María et al. (2004).

Studying the activity responses of broiler chickens to an increase in the complexity of the rearing environment, Bizeray et al. (2002) found that the use of barriers within the house, maintaining the same environmental conditions, led to changes in the feeding and drinking patterns. Broiler activity is known to be influenced by environmental temperature. The influence of physical microenvironment on animal physiological responses and related performance was well demonstrated (Mount, 1979; Deaton et al., 1997). The combined effects of temperature and relative humidity are considered critical in determining the chicken's ability to dissipate heat and to avoid losses caused by heat stress. Xin et al. (1994) studied the efficiency of houses designed for improved energy use by comparing ventilation systems and different evaporative cooling systems. In this work, the authors used the combination of air temperatures above $24^{\circ} \mathrm{C}$ with relative humidity above $80 \%$, in average, as critical environment. They also quantified broilers responses to thermal environments as expressed by flock productivity, air quality, and animal welfare.

Feed restriction applied to female broiler breeders may significantly increase bird stress, and influence their behavioral responses (Jong et al., 2003). These authors studied the behavior of Hybro-G female breeders in order to evaluate five different feed restriction regimes (90\%, 70\%, 50\%, 35\%, and 25\% from ad libitum intake) using ten birds per treatment. It was found that laying down and idle time were the only behavioral responses affected by the treatments. Savory \& Lariviere (2000) tested the effect dietary fiber addition on the ingestion behavior of broiler breeders to check if feeding motivation was reduced when qualitative instead of quantitive feed restriction was used. The relation between growth rate suppression and general activity level was also examined. In this study, 2-15 week-old female broiler breeders were divided in six groups of 20 birds, being each group submitted to a different feeding regime. Results showed that qualitative feed restriction resulted in higher welfare standards, and this research work has been used to subsidize welfare regulations.
Broiler Breeder Behavior and Egg Production as Function of Environmental Temperature

Martrenchar et al. (1997), studied stocking densities and behavioral responses of broilers, and concluded that $43 \mathrm{~kg} / \mathrm{m}^{2}$ negatively affected welfare, as measured by behavioral, physiological, and productive parameters in comparison to a stocking density of 27 $\mathrm{kg} / \mathrm{m}^{2}$.

The objective of the present research work was to study the influence of environmental temperature on the behavioral responses of female broiler breeders. Performance data, including egg production, eggshell resistance, and egg mass, of birds housed in an environmentally controlled chamber were also studied. The possibility of using a specific behavioral response as assessment of welfare was considered.

\section{MATERIALS AND METHODS}

The experiment was conducted from December, 2003 to January, 2004 in an environmentally-controlled chamber in the Agricultural Engineering College, FEAGRIUNICAMP, at Campinas, São Paulo, Brazil, located at $22^{\circ}$ $53^{\prime} \mathrm{S}$ latitude and $47^{\circ} 03^{\prime} \mathrm{W}$ longitude. The aim of this study was to verify bird behavioral response, egg production, and eggshell resistance to the following variables: environmental temperature, bird age, and dietary metabolizable energy content. The study lasted nine sequential days, and a Latin Square experimental design, as described in Table 1, was applied.

\begin{tabular}{|c|c|c|c|}
\hline Age (weeks) & $\begin{array}{c}\text { Days } 1,2,3 \\
13^{\circ} \mathrm{C}\end{array}$ & $\begin{array}{c}\text { Days } 4,5,6 \\
21^{\circ} \mathrm{C}\end{array}$ & $\begin{array}{c}\text { Days } 7,8,9 \\
35^{\circ} \mathrm{C}\end{array}$ \\
\hline 38 & 2,790 kcal & 2,810 kcal & $2,800 \mathrm{kcal}$ \\
\hline $46-48$ & $2,800 \mathrm{kcal}$ & $2,790 \mathrm{kcal}$ & $2,810 \mathrm{kcal}$ \\
\hline 56 & $2,810 \mathrm{kcal}$ & $2,800 \mathrm{kcal}$ & $2,790 \mathrm{kcal}$ \\
\hline
\end{tabular}

Birds: Twenty seven Hybro-PG ${ }^{\circledR}$ female broiler breeders of three different ages (38 weeks of age, $\mathrm{n}=9$; 46-48 weeks of age, $\mathrm{n}=9$; and 56 weeks of age, $\mathrm{n}=9$ ) were randomly selected from a commercial flock.

Environmental Conditions: Inside the environmental chamber, three different air temperatures $\left(13^{\circ} \mathrm{C}, 21^{\circ} \mathrm{C}\right.$, and $35^{\circ} \mathrm{C}$ ) were used in each trial. Relative air humidity was kept constant at $75 \%$. Each environmental condition was kept constant for three days in order to observe birds behavioral response (Table 1). Each pen was equipped with a nesting area and a suspended feeder, similar to those provided in commercial broiler breeder houses.

Feed Ration: Three different feed formulations, 


\section{Pereira DF, Nääs IA, Romanini CEB, Salgado DD, Pereira GOT}

including corn, soybean meal, dicalcium phosphate, limestone, sodium chloride, provided the same crude protein, and mineral and vitamin contents, but three different metabolizable energy levels $(2,810 \mathrm{kcal} / \mathrm{kg}$; $2,800 \mathrm{kcal} / \mathrm{kg}$; and 2,790 kcal/kg). metabolizable energy.

Experimental method: For each environmental condition, each pen housed three female broiler breeders, one of each age group. Each group of breeders was fed a different dietary energy content. The diagram of the pens is shown in Figure 1. For each environmental condition, flocks were changed to avoid the impact of continuous heat stress exposure on the birds. During the time outside the chamber, the breeders were reared nearby, inside a small-scale open aviary. Birds in each trial (total of nine birds) were not randomly selected, but in a way to never have the same birds in order not over stressing them. Once placed inside the chamber, the birds remained for one day for acclimatization at an environmental temperature of $24^{\circ} \mathrm{C}$, after which the temperature was raised up to the established limit. The trials days described in Table 1 correspond to the period of exposure to the combined factors: air temperature, age, and feed energy level.
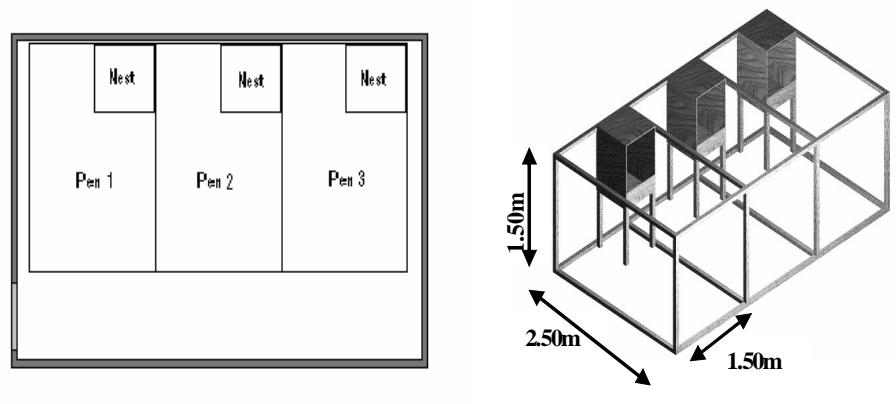

Figure 1 - Diagrams of pens and nest distribution inside the environmental chamber.

Table 1 shows that during days 1,2 , and 3 , all birds according to the age group (38, 46-48 and 56 weeks old) were exposed at the same time to an environmental temperature of $13^{\circ} \mathrm{C}$. The 38 weekold group received the feed containing $2,810 \mathrm{kcal} / \mathrm{kg}$ of metabolizable energy; the 46-48 week-old group was fed the diet containing 2,800 $\mathrm{kcal} / \mathrm{kg}$; and the 56-week-old group was fed the diet containing 2,790 $\mathrm{kcal} / \mathrm{kg}$ metabolizable energy. For each air temperature and relative humidity environmental condition, breeders were exposed for $24 \mathrm{~h}$ to thermoneutral conditions $\left(24^{\circ} \mathrm{C}\right.$ and $\left.75 \%\right)$ for
Broiler Breeder Behavior and Egg Production as Function of Environmental Temperature

acclimatization in order to make the flocks more uniform at the beginning of each trial. The adopted feeding management was restricted to a fixed amount of $150 \mathrm{~g} / \mathrm{bird} /$ day once a day, which was fed from 6:007:00h. The amount of feed was controlled and calculated based on the breeders productive phase, maintaining the same procedure used at the commercial farm where the breeders originally came from.

Recording of behavior: All behaviors described in Table 2 were continuously recorded by polychromatic video cameras installed on the upper part of the environmental chamber facing downwards, and on the upper part of the nests (Figure 2).

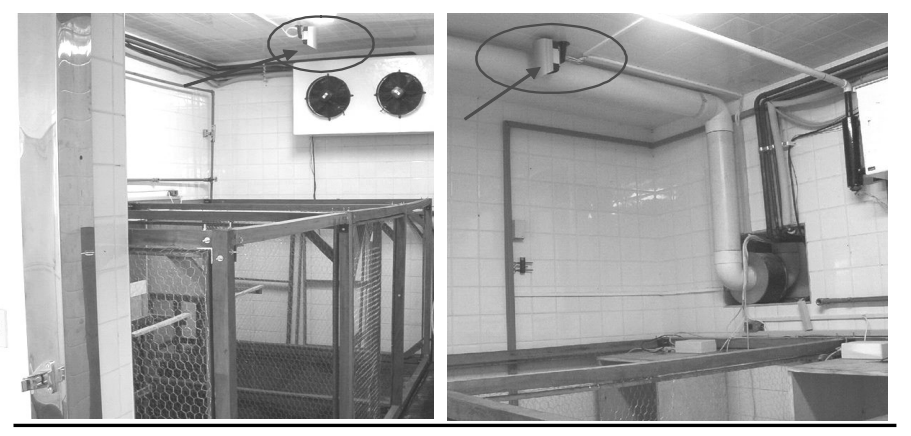

Figure 2 - View of the video camera placed in the geometrical center of the environmental chamber and the pens.

Behavioral patterns was divided into two: normal or aggressive, as suggested by Estevez et al. (2003). Normal behavior was considered as time spent resting, walking around, eating, foraging, and drinking water naturally, while aggressive behavior was related to interaction with other birds. Panting, a recognized potential indicator of heat stress, could not be used due to video camera limitations. There was no human interference in the recording process; observations were performed remotely and at real time.

The morning period was considered as the time interval between 6:00 am and 12:00 pm, and the afternoon period was considered as the time period between 12:00 pm and 06:00 pm. Lapse-time video recording samples of $15 \mathrm{~min}$ in the morning, and 15 min in the afternoon were randomly chosen to be observed, as suggested by Bizeray et al. (2002) and Estevez et al. (2003).

Egg data recording: The response parameter: number of eggs laid daily, egg weight and volume, and egg shell resistance were recorded for each pen. The eggs were collected daily, counted, and weighed, 


\begin{tabular}{ll}
\hline $\begin{array}{l}\text { Table } 2 \text { - Ethogram of recorded behaviors. } \\
\text { Behavioral category }\end{array}$ & Definition \\
Normal & A complex behavioral repertoire identified by the bird laying on its side, displaying at least one leg to the side and \\
Dust Bathing & The bird is pecking or scratching at the substrate. \\
Foraging & The beak is moving whilst touching another part of the body of the hen. \\
$\begin{array}{l}\text { Preening } \\
\text { Stretching }\end{array}$ & The act of the bird to spread one leg at the same time it spreads the wing \\
Nesting & The bird inside the nest box. \\
Open wings & The bird opens both wings at the same time for several times, including clapping them together \\
Pecking & Sharp forward movements with the head towards an object or conspecific, as sequences of pecking and scratching in \\
& the floor. Italso included pecking at small particles at the floor \\
Feather bristle & A noticeable increase in the feather volume all over the body \\
Resting Stationary & Either standing or sitting \\
Prostration & The bird was laying down with the head slightly bending down \\
Running & The bird performed a very rapid displacement for more than $30 \mathrm{~cm}$, in a random direction without any specific reason \\
Laying down & The bird lay down in an attitude of resting (idle) \\
Aggressive & The bird running after another \\
Chasing & One bird tried to climb over the other \\
Mounting & Sharp forward movements with the head towards other bird \\
Pecking other & An encounter in which a bird stands with the neck erect and feathers raised in front of a second bird that had its head \\
Threatening & at a lower level \\
\hline
\end{tabular}

using precision scale, and the volume was recorded using a water volume difference by submerging the egg inside a graduate becker. Eggs were then submitted to compression test using Instrom ${ }^{\circledR}$ with the aim of measuring eggshell resistance to breaking. The compression cell used was $10 \mathrm{kgf}$, and the egg was placed with its larger dimension in the same direction of the compression force until breaking. Strain measurement was registered in a computer, using a software that determines the exact instant when the eggshell cracks.

Experimental statistical design: A $3 \times 3 \times 3$ Latin Square experimental statistical design used with three bird ages, three environmental temperatures, and three dietary energy levels (Table 1). As opposed to a statistical factorial design, not all the combinations between treatments are possible when using Latin Square. However, it reduces experimental time, and it has been adopted in trials for animal behavior studies (Weng et al., 1998; Sibbald et al., 2000; Doreau et al., 2004). Data was processed using Minitab ${ }^{\circledR}$ statistic software. The observation of residual values of the distribution graph versus predicted values showed that there was homogeneity of variance, and thus data were processed assuming homogeneity.

Tukey's test was applied to determine the correlation of events, while ANOVA quantified the significance of the results. As environmental temperature fluctuation implies in minimum values during the morning and maximum values in the afternoon, the behavior analysis was done separately for both periods.

\section{RESULTS AND DISCUSSION}

\section{Behavioral time budget of the breeders}

Relative occurrences of individual behaviors significantly varied according to the time of the day, and were related to feeding strategy.

\section{Egg production, weight and eggshell resistance}

Results are presented in Table 3 and 4 . On days 5, 7, 8, and 9, no egg was laid. Table 3 shows Tukey's test results for the number of eggs laid per pen as function of the thermal environmental conditions.

There was no effect of treatments on egg production $(p<0.05)$, except for environmental temperature. Table 3 shows that there was no egg production at $35^{\circ} \mathrm{C}$ (days 7, 8 and 9). Other authors (Costa, 1994; Sahim et al., 2002) observed that when the experimental temperature was above the thermoneutral temperature range, there was a reduction in egg production.

Costa (1994) proposed that the thermoneutral zone for broiler breeders should remain in the range of approximately $18^{\circ} \mathrm{C}$ to $29^{\circ} \mathrm{C}$. Pereira (2003) studying female broiler breeder thermal preference, found the thermoneutral zone ranged from $16^{\circ} \mathrm{C}$ to $31^{\circ} \mathrm{C}$. As $21^{\circ} \mathrm{C}$ is within the thermoneutral zone value, higher egg production was expected in this treatment; however, as this did not happen, this result was probably related to other non-controlled factors. The small number of birds and the applied experimental design (Latin Square) did not allow a 
Pereira DF, Nääs IA, Romanini CEB, Salgado DD, Pereira GOT statistical evaluation of isolated factors, indicating that this statistical design may not be adequate for evaluating egg production in particular.

\begin{tabular}{|c|c|}
\hline \multicolumn{2}{|c|}{$\begin{array}{l}\text { Table } 3 \text { - Results for average egg production according to tem- } \\
\text { perature treatment. }\end{array}$} \\
\hline $\begin{array}{l}\text { Tukey's test results } \\
\text { (average number of eggs laid) }\end{array}$ & Temperature \\
\hline $1.00 \mathrm{ab}$ & $13^{\circ} \mathrm{C}$ \\
\hline $2.67 \mathrm{a}$ & $13^{\circ} \mathrm{C}$ \\
\hline $1.33 \mathrm{ab}$ & $13^{\circ} \mathrm{C}$ \\
\hline $1.33 \mathrm{ab}$ & $21^{\circ} \mathrm{C}$ \\
\hline $0.00 \mathrm{~b}$ & $21^{\circ} \mathrm{C}$ \\
\hline $1.33 \mathrm{ab}$ & $21^{\circ} \mathrm{C}$ \\
\hline $0.00 \mathrm{~b}$ & $35^{\circ} \mathrm{C}$ \\
\hline $0.00 \mathrm{~b}$ & $35^{\circ} \mathrm{C}$ \\
\hline $0.00 \mathrm{~b}$ & $35^{\circ} \mathrm{C}$ \\
\hline
\end{tabular}

Tukey's test: Values in the same column followed by different letters are statistically different $(p<0.05)$.

\section{Effect of feeding strategy on behavioral responses}

Behavior data were separately analyzed for the morning and the afternoon. As mentioned above, behaviors were divided in two expected responses: normal or aggressive. Table 5 shows the statistical analysis of behavior occurrences in the morning, when breeders were fed.

Stretching presented significant statistical differences $(p<0.05)$ as function of environmental temperature, being more evident at $13^{\circ} \mathrm{C}$, and decreasing slightly as environmental temperature increased. Prostration was not recorded in the morning, while dust bathing was not observed either in the morning or in the afternoon.

Table 6 shows Tukey's test results for aggressive behavior in the morning. Younger birds (38 weeks) presented higher frequency of chasing $(p<0.05)$, but this frequency decreased as birds grew older. Associated to non-aggressive behaviors, these results
Broiler Breeder Behavior and Egg Production as Function of Environmental Temperature

showed that 38-week-old birds tended to be more active than the older ones. Chasing and pecking frequencies were significantly higher $(p<0.05)$ at $13^{\circ} \mathrm{C}$. This significant increase in aggressive behavior at lower temperatures was also observed by Estevez et al. (2003) and Pettit-Riley et al. (2002). This is probably due to feed competition, and may be considered as a tool for welfare assessment.

Aggressive behaviors were not observed during the afternoon. In natural habitats, chickens remain in small groups, and the dominant social hierarchy is based on individual fights (Eath \& Keeling, 2003). In this experiment, birds rested and explored the area during the afternoon. Estevez et al. (2003) describes that young layers (3-18 weeks of age) tend to show reduced aggressive behavior as a group strategy when group size is higher than $5 \mathrm{birds} / \mathrm{m}^{2}$. This density was similar to that used in this trial. The results led to the correlation of aggressive behavior with feed competition, which, in present study, increased in low environmental temperature.

Table 7 shows the results of non-aggressive behaviors during the afternoon. During the afternoon, non-aggressive behaviors last longer than during the morning apparently due to fact that birds did not have an element for fighting (feed).

\section{Effect of age}

Age affected running behavior of younger birds (38 weeks), as they tended to run more than the older ones (44-46 weeks and 56 weeks). Younger breeders also tended to be more aggressive than older ones when fighting for feed.

\section{Effect of feed energy}

Feed energy affected the behavior of opening

\begin{tabular}{|c|c|c|c|c|c|c|}
\hline & Flock (weeks) & Feed ration (kcal) & \# of eggs laid & Egg weight (g) & Egg volume (ml) & Egg shell resistance (N) \\
\hline \multirow[t]{3}{*}{ Day 1} & 38 & 2790 & 2 & 67.35 & 58.00 & 58.07 \\
\hline & $46-48$ & 2800 & 1 & 69.58 & 60.00 & 53.32 \\
\hline & 56 & 2810 & 0 & - & - & - \\
\hline \multirow[t]{3}{*}{ Day 2} & 38 & 2790 & 3 & 63.04 & 56.7 & 45.77 \\
\hline & $46-48$ & 2800 & 2 & 67.84 & 59.5 & 43.83 \\
\hline & 56 & 2810 & 3 & 60.91 & 52.7 & 48.63 \\
\hline \multirow[t]{3}{*}{ Day 3} & 38 & 2790 & 1 & 70.83 & 61 & 48.8 \\
\hline & $46-48$ & 2800 & 3 & 64.68 & 56.7 & 51.36 \\
\hline & 56 & 2810 & 0 & - & - & - \\
\hline \multirow[t]{3}{*}{ Day 4} & 38 & 2790 & 2 & 62.60 & 57.5 & 50.07 \\
\hline & $46-48$ & 2800 & 2 & 70.10 & 63.5 & 47.51 \\
\hline & 56 & 2810 & 0 & - & - & - \\
\hline \multirow[t]{3}{*}{ Day 6} & 38 & 2790 & 2 & 63.52 & 57.00 & 53.53 \\
\hline & $46-48$ & 2800 & 2 & 68.52 & 60.5 & 52.62 \\
\hline & 56 & 2810 & 0 & - & - & - \\
\hline
\end{tabular}


Pereira DF, Nääs IA, Romanini CEB, Salgado DD, Pereira GOT

\begin{tabular}{|c|c|c|c|c|c|c|c|}
\hline \multirow[t]{2}{*}{ Treatment } & \multicolumn{6}{|c|}{ Behavior } & \multirow[b]{2}{*}{ Feather bristling } \\
\hline & Preening & Stretching & Running & Laying down & Foraging & Opening wings & \\
\hline $13^{\circ} \mathrm{C}$ & 0.78 & $0.00 \mathrm{~b}$ & $2.00 a$ & 0.67 & 0.78 & $1.33 a$ & $1.78 \mathrm{a}$ \\
\hline $21^{\circ} \mathrm{C}$ & 0.33 & $0.22 a b$ & $0.22 a$ & 0.22 & 0.89 & $1.11 \mathrm{a}$ & $0.78 a b$ \\
\hline $35^{\circ} \mathrm{C}$ & 0.11 & $0.67 a$ & $0.67 a$ & 0.00 & 1.22 & $0.56 a$ & $0.33 b$ \\
\hline 38 weeks & 0.44 & $0.56 a$ & $2.33 a$ & 0.22 & 1.11 & $0.44 a$ & $0.89 a$ \\
\hline 46-48 weeks & 0.33 & $0.22 a$ & $0.22 b$ & 0.11 & 1.11 & $1.33 a$ & $1.00 \mathrm{a}$ \\
\hline 56 weeks & 0.44 & $0.11 a$ & $0.33 b$ & 0.56 & 0.67 & $1.22 \mathrm{a}$ & $1.00 \mathrm{a}$ \\
\hline $2,790 \mathrm{kcal}$ & 0.44 & $0.00 a$ & $1.56 a$ & 0.22 & 0.22 & $0.22 b$ & $0.56 a$ \\
\hline $2,800 \mathrm{kcal}$ & 0.56 & $0.56 a$ & $1.00 a$ & 0.33 & 1.22 & $2.00 \mathrm{a}$ & $1.44 a$ \\
\hline $2,810 \mathrm{kcal}$ & 0.22 & $0.33 a$ & $0.33 a$ & 0.33 & 1.44 & $0.78 a b$ & $0.89 a$ \\
\hline
\end{tabular}

Tukey's test: Values in the same column followed by different letters are statistically different $(p<0.05)$.

\begin{tabular}{|c|c|c|c|c|}
\hline \multicolumn{2}{|c|}{ Treatment } & \multicolumn{2}{|c|}{ Behavior } & \multirow[b]{2}{*}{ Pecking } \\
\hline & eatening & Chasing & Mounting & \\
\hline $13^{\circ} \mathrm{C}$ & 0.66 & $1.11 a$ & 0.11 & $5.22 a$ \\
\hline $21^{\circ} \mathrm{C}$ & 0.00 & $0.11 b$ & 0.00 & $0.33 b$ \\
\hline $35^{\circ} \mathrm{C}$ & 0.00 & $0.00 \mathrm{~b}$ & 0.00 & $1.44 b$ \\
\hline 38 weeks & 0.11 & $1.00 a$ & 0.11 & $3.88 a$ \\
\hline 46-48 weeks & 0.22 & $0.00 \mathrm{~b}$ & 0.00 & $0.88 a$ \\
\hline 56 weeks & 0.33 & $0.22 \mathrm{ab}$ & 0.00 & $2.22 \mathrm{a}$ \\
\hline $2,790 \mathrm{kcal}$ & 0.11 & $0.88 a$ & 0.11 & $2.88 a$ \\
\hline $2,800 \mathrm{kcal}$ & 0.22 & $0.00 a$ & 0.00 & $1.77 a$ \\
\hline $2,810 \mathrm{kcal}$ & 0.33 & $0.33 a$ & 0.00 & $2.33 a$ \\
\hline
\end{tabular}

Tukey's test: Values in the same column followed by different letters are statistically different $(p<0.05)$.

wings, and this behavior was more frequent $(p<0.05)$ when birds were fed the diet containing 2,800 kcal/ $\mathrm{kg}$. It was found that feeding was the most important factor related to the conflicts among birds, being responsible for aggressive behaviors. However, these findings in a small sample of birds observed under specific conditions may not necessarily reflect group response, as pointed by Estevez et al. (2003).

Differences in the frequency of occurrence of certain behaviors due to the quality of feed restriction were observed by Jong et al. (2003) and Savory \& Lariviere (2000). Opposed to Jong et al. (2003), no significant differences in the laying down behavior due to feeding restriction were observed in the present experiment. However, this disparity may be partially explained by the results of Martrenchar et al. (1997), who concluded that the increase in bird density may negatively affect welfare, as determined by physiological and productive parameters.

\section{Effect of environmental temperature}

Prostration and laying down were inversely proportional to environmental temperature. Breeders tended to lay down for resting when environmental temperature was mild. When environmental temperature was high breeders showed higher foraging activity and less wing opening, in agreement with Deaton et al. (1997). María et al. (2004) stated that locomotory activities significantly decrease due to exposure to thermal stress, and this was observed in the present experiment as there was a positive correlation between high environmental temperature and prostration. Preening and foraging during the afternoon were significantly different $(p<0.05)$ as a function of environmental temperature. These behaviors were more frequent at $13^{\circ} \mathrm{C}$, and gradually decreased as environmental temperature increased. These behaviors can also be used to assess welfare related to thermal environment.

Preening behavior was not significant; however, Kristensen et al. (2000) and Wathes et al. (2002) relate this behavioral response to an aversion to specific environmental characteristics, such as high

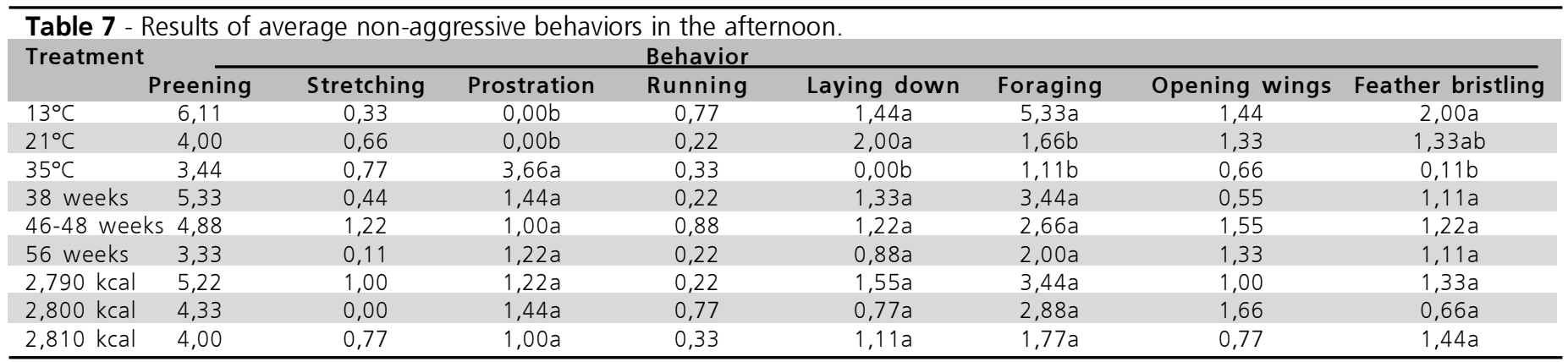

Tukey's test: Values in the same column followed by different letters are statistically different $(p<0.05)$. 
Pereira DF, Nääs IA, Romanini CEB, Salgado DD, Pereira GOT
Broiler Breeder Behavior and Egg Production as Function of Environmental Temperature environmental temperature associated to high ammonia concentration.

Aggressive behavior when competing for feed increased in the low environmental temperature. Eicher \& Wechsler (1997) described the negative influence of feather pecking on poultry welfare. In the present experiment, there was a higher frequency of pecking at an environmental temperature of $13^{\circ} \mathrm{C}$ (below thermoneutral zone). This may be due to a higher demand of metabolizable energy for body temperature maintenance. Although there was not a statistically significant difference in the frequency of feather pecking at environmental temperatures of $21^{\circ} \mathrm{C}$ and $35^{\circ} \mathrm{C}$, the values were numerically smaller at $21^{\circ} \mathrm{C}$ (within the thermoneutral zone). The behavioral expression of chasing others decreased with as environmental temperature increased, confirming the predictions of María et al. (2004).

\section{CONCLUSIONS}

The variable that most influenced egg production was environmental temperature. When exposed to cold environment, birds exercised more their muscles by dust bathing and feather bristling as mechanisms of reaction to chilling. At the high environmental temperature, birds presented the behaviors of laying down or prostrating. Younger birds presented higher frequency of movements, such as running and chasing others. As behaviors were correlated both to age and environmental temperature, it is possible to build simulation models of welfare assessment based on the frequency of specific behaviors, such as preening, stretching, prostration and laying down.

\section{REFERENCES}

Arnould C, Faure JM. Use of pen space and activity of broiler chickens reared at two different densities. Applied Animal Behaviour Science 2004; 87(1-2):155-170.

Bizeray D, Estevez I, Leterriera C, Faurea JM. Effects of increasing environmental complexity on the physical activity of broiler chickens. Applied Animal Behaviour Science 2002; 79(1):27-41.

Campos EJ. O comportamento das aves. Revista Brasileira de Ciência Avícola, 2000; 2(2):93-113.

Costa CA. Pontos Críticos do manejo de matrizes. In: Conferência Apinco de Ciência e Tecnologia Avícola: Manejo de Matrizes; 1994; Campinas. Anais... Campinas: Fundação Apinco de Ciência e Tecnologia Avícolas; 1994. p.1-10.
Dawkins MS. Behaviour as a tool in the assessment of animal welfare. Zoology 2003; 106:383-387.

Deaton JW, Reece FN, McNaughton N. The effect of temperature during the growing period on broiler performance. Poultry Science 1997; 57:1070-1074.

Doreau MB, Doreau M, Béchet G. Effect of underfeeding on digestion in cows. Interaction with rumen degradable $\mathrm{N}$ supply. Livestock Production Science 2004; 88(1-2):33-41.

Duncan IJH, Mench JA. Behaviour as an indicator of welfare in various systems. Basic Biology and Welfare. Alternative Housing Systems 1993; 7:69-76.

Eath RBD, Keeling $\sqcup$. Social discrimination and aggression by laying hens in large groups: from peck orders to social tolerance. Applied Animal Behaviour Science 2003; 84:197-212.

Eicher $\mathrm{BH}$, Wechsler $\mathrm{B}$. Feather pecking in domestic chicks: its relation to dustbathing and foraging. Animal Behaviour 1997; 54:757768.

Estevez I, Keeling L, Newberry RC. Decreasing aggression with increasing group size in young domestic fowl. Applied Animal Behaviour Science 2003; 84:213-218.

Jong IC, Vooerst SV, Blokhuis HJ. Parameters for qualification of hunger in broiler breeders. Physiology \& Behavior 2003; 78:773783.

Kristensen HH, Burgess LR, Demmers TGH, Wathes CM. The preferences of laying hens for different concentrations of atmospheric ammonia. Applied Animal Behaviour Science 2000; 68:307-318.

María GA, Escós J, Alados CL. Complexity of behavioural sequences and their relation to stress conditions in chickens (Gallus gallus domesticus): a non-invasive technique to evaluate animal welfare. Applied Animal Behaviour Science 2004; 86:93-104.

Martrenchar A, Morisse JP, Huonnic D, Cotte JP. Influence of stocking density on some behavioural, physiological and productivity traits broiler. Veterinary Research 1997; 28(5):473-480.

Mount LE. Adaptation to thermal environment. man and his productive animals. London: Edward Arnold Publishers; 1979. 213p.

Pereira DF. Avaliação do comportamento individual de matrizes pesadas (frango de corte) em função do ambiente e identificação da temperatura crítica máxima [dissertação]. Campinas (SP): FEAGRIUNICAMP; 2003.

Pettit-Riley R, Estevez I, Russek-Cohen E. Effects of crowding and access to perches on aggressive behaviour in broiler. Applied Animal Behaviour Science 2002; 79:11-25.

Puma MC, Xin H, Gates RS, Burnham DJ. An instrumentation system for studying feeding and drinking behaviour of individual poultry. Applied Engineering in Agriculture 2001; 17(3):365-374.

Sahim K, Sahim N, Onderci M. Vitamin E supplementation can 
alleviate negative effects of heat stress on egg production, egg quality, digestibility of nutrients and egg yolk mineral concentrations of Japanese quails. Research Veterinary Science 2002; 73:307-312.

Savory CJ, Lariviere JM. Effects of qualitative and quantitative food restriction treatments on feeding motivational state and general activity level of growing broiler breeders, Applied Animal Behaviour Science 2000; 69:135-147.

Sibbald AM, Shellard LF, Smart TS. Effects of space allowance on the grazing behaviour and spacing of sheep. Applied Animal Behaviour Science 2000; 70(1):49-62 